\title{
Residents' Attitude toward Tourism-Do the Benefits Outweigh the Downsides? The Case of Constanta, Romania
}

\author{
Andreea-Daniela Moraru ${ }^{1}$, Cristina Duhnea ${ }^{1, *(\mathbb{D})}$, Alina Barbulescu ${ }^{2, * \mathbb{D}}$, Mariana Juganaru ${ }^{1}$ and \\ Ion-Danut Juganaru ${ }^{1}$
}

1 Department of Business Administration, “Ovidius” University of Constanta, 900527 Constanta, Romania; amoraru@univ-ovidius.ro (A.-D.M.); mjuganaru@univ-ovidius.ro (M.J.); djuganaru@univ-ovidius.ro (I.-D.J.)

2 Department of Civil Engineering, "Transilvania" University of Brașov, 500152 Brașov, Romania

* Correspondence: cristinaduhnea@univ-ovidius.ro (C.D.); alinadumitriu@yahoo.com (A.B.)

Citation: Moraru, A.-D.; Duhnea, C.; Barbulescu, A.; Juganaru, M.; Juganaru, I.-D. Residents' Attitude toward Tourism-Do the Benefits Outweigh the Downsides? The Case of Constanta, Romania. Sustainability 2021, 13, 882. https://doi.org/ $10.3390 /$ su13020882

Received: 27 December 2020 Accepted: 15 January 2021 Published: 17 January 2021

Publisher's Note: MDPI stays neutral with regard to jurisdictional clai$\mathrm{ms}$ in published maps and institutional affiliations.

Copyright: $(\odot 2021$ by the authors. Licensee MDPI, Basel, Switzerland. This article is an open access article distributed under the terms and conditions of the Creative Commons Attribution (CC BY) license (https:// creativecommons.org/licenses/by/ $4.0 /)$.

\begin{abstract}
While the positive economic impact of tourism cannot be denied, it has also a number of negative side effects. The article focuses on the residents' perception regarding the tourist activity and on identifying the factors influencing their acceptance for the tourist activity, in Constanta (Romania). A questionnaire based quantitative research was employed, creating several indexes, subsequently included in econometric models in order to reveal the factors which determine residents acceptance and support for tourism. The results reveal that residents are highly in favour of tourism activity and support tourism expansion and further development. Most respondents considered that tourism contributed to the improvement of the city image and identified a fairly positive economic impact, while tourism was accountable for the increase in several negative phenomena. The impact of tourist activity on the sustainable development of the city was perceived as medium positive, while most respondents considered that the number of tourists should increase. The residents' acceptability toward tourism was revealed to depend on several variables and computed indexes: city development index, impact on residents' quality of life index, sustainable development index, and perceived intensity of contact with tourists.
\end{abstract}

Keywords: tourism; residents; attitude; sustainable development

\section{Introduction}

It is undeniable that tourism has a positive economic effect potentiating the general development, creating professional opportunities and jobs, and increasing public income. At the same time, it causes significant negative side effects, such as overcrowding, excessive building, pollution, or increase in criminal offenses. Given this binary nature of tourism, as well as its general spectacular development during the past few decades, specialised literature has been dedicated to analysing the relationship between tourists and residents, under its multiple forms of manifestation.

Tourism is considered a source of enhancing the economic development of local and regional communities [1-3], but we cannot ignore the effects that the tourism industry has on those communities. From the several angles tackled in the research emerges the general opinion that the economic effect is a positive one as opposed to the social and environmental aspects of tourists' presence in the day-to-day life of a community, which are considered to have a rather negative impact, especially in the long term [4-6].

Many studies stated that, to ensure the sustainable development of the tourism industry, it is absolutely necessary to get the involvement of the host community [7]. The key to achieving that is to determine correctly the perception of the residents, based on their beliefs and opinions, and how they influence the level of support for tourist destination development.

The research on residents' perceptions on tourists' presence in a community has proliferated significantly since the 1970s. 
A synthesis of such studies shows that the interest for conducting investigations is divided into studies that address urban tourist destinations and rural tourism destinations [7-9]. Other studies focused on mountainous areas $[10,11]$, islands where the main economic activity is tourism [12-14], or tourist destinations with main attractions such as anthropogenic or natural parks and cultural and historical attractions included in the World Heritage Sites list $[15,16]$. Many studies focused on the perception/attitudes of residents regarding the tourists and the impact that tourism has on cities, especially historical/cultural cities. On the one hand, studies investigating the residents' perception about the tourism impact are centred on cities from developed countries, such as Cardoso and Silva's in Porto, Portugal [17], Koens and Postma's in six European cities [18], Escudero Gomez in Toledo, Spain [19], Janusz et al. in Bruges [20], Gilbert and Clark in Canterbury and Guildford [21] or Ross [22] in Australian cities. Other studies which presented the image of the residents' attitudes and perception in a developing country are Tichaawa and Moyo in cities from Zimbabwe [23] and Rogerson in Johannesburg [24].

Several studies investigated the economic impact of tourism on the development of the communities. Haralambopoulos and Pizam [25] found that the presence of tourists led to higher tax revenue and personal income and an overall better standard of living, but residents considered it led to price increases. In line with these findings, Liu and Var [5] noted that investments, employment rate, and flourishing local businesses are clearly positive effects of tourism, but they come with a higher cost of living for residents. Brunt and Courtney [26] reached the same conclusion identifying a positive impact on employment rate but also noting higher prices for goods and services.

Recent studies focused on the social effects of the presence of tourists in the community. They dealt mainly with two core concepts: quality of life [27-32] and well-being [33].

The research conducted so far revealed a diversity of negative aspects that affect the quality of life of residents when tourists are present in their community: crime [26,32], drugs [25,32], rise in alcohol consumption [34], prostitution [35], or reduced resident hospitality [5].

When it comes to environmental issues, spatial planning, and landscaping, the negative effects include traffic and parking difficulties [26,31,35-37], vandalism [37], overcrowding of parks, congestion on streets [3,26,36], and litter [26,29].

The research regarding the attitudes of residents towards tourists was developed based on several theories. The most discussed is the social exchange theory (SET) having the starting point a conceptual framework created by Ap [4] to explain the positive and negative perceptions of residents and implemented in the economic research as economic exchange theory [4,38-42]. The stakeholder theory focuses on different stakeholder categories such as residents, entrepreneurs, government officials, and managers/hoteliers [43-45]. Weber's theory of formal and substantive rationality (WFSR) considers human rationality as being influenced by a balance between one's formal (economic) and substantive (non-economic) motivations [3,46]. The WFSR theory is more appropriate than SET to investigate the attitudes of residents. Basically, since Weber considered that rationality for economic activity may be formal or substantive [47], the investigation makes room for the individual values, beliefs, morals, and emotional personal perceptions to be under scrutiny without excluding the economic aspects that have impact on attitudes [3]. Mody et al. [48] studied the residents' attitude by designing a framework that encompassed Weber's theory of rationality and the Foucauldian concepts of power, knowledge, and governmentality.

Moreover, several models and econometric instruments have been used to test different theories regarding the residents' attitudes. Maddox [49] used the critical incident technique to study residents' satisfaction with local tourism. Davis et al. [50] summarised and clustered the attitudes of residents regarding tourism development in Florida, while Perez and Nadal [14] conducted a cluster analysis on the Balearic Islands. Perdue et al. [31] developed a model, the resident attitudes toward tourism, to test the SET theory. Boley et al. [46] developed and used the resident empowerment through tourism scale (RETS) and in another study developed sub-scales of psychological, social and political empow- 
erment [51]. Other authors composed relevant indexes to underpin the effects of tourism and to measure the level of acceptability and support of residents for tourism development in their community [52]. Meimand et al. [53] studied the socio-cultural impact of tourism, including religion. Vargas and Porras-Bueno [54] included seasonality in their research construct.

During the past four decades, a consistent body of literature has been dedicated to overtourism, which occurs when the number of tourists exceeds the carrying capacity of the tourist destination. More recently, attention has been paid to the way the pressure of overtourism influences the residents' attitude towards tourist activity [55-66].

The present article focuses on the residents' perception regarding the tourist activity and identifying the factors that determine their acceptance and support for the tourist activity in their community. The research was conducted in a city on the Black Sea coast, Constanta, Romania. Considering the importance of the tourist industry to the overall development of Constanta city, the need to investigate how the residents perceive the tourism phenomenon and tourists interfering with their day-to-day life has emerged. Our study adds to the existing literature by filling the gap regarding the research of residents' attitude toward tourism in a coastal city, accommodating a great number of tourists during a short tourist season. Moreover, to our knowledge, the present study is the first which attempts an investigation of this kind in Romania, previous studies covering only marginally the residents' perception on tourism $[67,68]$. To this end, we conducted a questionnaire-based quantitative research. We used numerous variables and created indexes, and subsequently included them in econometric models in order to reveal the factors which determine residents' acceptance and support for tourism.

The objectives of the research are:

- evaluate the perceived impact of tourism on the image of the city;

- reveal the perceived impact of tourism on the general development of the city;

- identify the residents' characterisation of tourists' behaviour;

- identify the impact of tourism effects on residents' lives and on the sustainable development of the city; and

- identify the residents' level of acceptance and support with regard to the tourist activity developed in their community and the factors influencing residents' acceptance.

The paper is structured as follows: introduction, the general context of tourist activity development in the city of Constanta, the research methodology, results and discussion, and, finally, conclusions.

\section{Materials and Methods}

\subsection{The General Context}

With an area of $7071 \mathrm{~km}^{2}$, Constanta County occupies the 8th place among the Romanian counties and the 5 th place according to the number of inhabitants $(764,021$ inhabitants, on 1 July 2019, according to the Constanta County Directorate of Statistics [69]). The county lies in the southeast of Romania, in the historical province of Dobrudja, bordered by the Danube and the Black Sea. Constanta city is the capital of the Constanta county, with an area of $125 \mathrm{~km}^{2}$ and 312,250 inhabitants (on 1 July 2019, according to data from the Constanța County Directorate of Statistics [69]). Constanta city is classified as a municipality, with a significant economic, social, political, and cultural role and having, as a rule, an administrative function. To the northern boundary of the city lies the tourist resort of Mamaia, which, from an administrative point of view, is actually a district of Constanta city [70]. Moreover, according to the administrative-territorial organisation, Constanta county includes the entire Romanian coast where lie a plethora of tourist resorts, from north to south, to the Bulgarian border: Mamaia Nord-Năvodari, Mamaia, Constanța, Eforie Nord, Eforie Sud, Techirghiol, Costinești, Neptun-Olimp, Jupiter, Cape Aurora, Venus, Saturn, Mangalia, 2 Mai, and Vama Veche. Therefore, Constanța city is both a holiday destination (for tourists staying in the city and in the Mamaia resort) and an attraction for 
tourists staying throughout the entire Romanian coast, for tourists on cruise ships docking in the port of Constanta, or for those touring the country.

The tourist activity due to its multiplier effect represents an important component for the stability and competitiveness of the local economy. Constanta is also a port city, the most important Romanian seaport, with an area of 3182 ha, but also the fourth largest port in Europe, after Rotterdam, Antwerp, and Marseille [71]. Besides tourism, in the economic profile of the city and county of Constanta, there are other fields of activity, such as shipbuilding, industrial and civil engineering, maritime and river transport, oil refining, renewable energy, gas, agriculture, trade, food industry, and services [72].

Constanta's tourist offer is the result of the combined and diversified capitalisation of natural and anthropic resources, many of them unique in the country or even in the world. Regarding the natural tourist potential, the most representative aspects to be mentioned are the beaches, the sea water, the geographical positioning, the climate, and the landscape conditions. The beaches in Constanța, guarded by numerous coves, stretch for about $13 \mathrm{~km}$ and are positioned throughout the eastern part of the city (which provides them with sunshine all day), from Tomis Port to Mamaia resort. A particular aspect is the access to the beach, which is reached from a very high cliff, descending a few dozen steps. The landscape, from the cliff, offers a beautiful panorama of the sea and the city. Mamaia, which is geographically a lagoon between the Black Sea and Siutghiol Lake, has a $6 \mathrm{~km}$ long, ground-level beach facing east [70]. The beaches of Constanța and Mamaia are wide (from 200 to $500 \mathrm{~m}$ ), have very fine white sand, and are sunny about $11 \mathrm{~h}$ a day (during the summer). The entrance into the sea water is smooth, the water having a very shallow depth, for tens of meters offshore [73]. All these represent specific aspects, through which the beaches of Constanța city (including Mamaia) differ from other countries, where the beaches are not oriented toward the east. The Black Sea water, with a complex chemical composition (chlorinated, sulphurised, magnesium, and sodium), has a low salinity of $17-18 \mathrm{mg} / \mathrm{L}$ and reaches temperatures even of $26-28{ }^{\circ} \mathrm{C}$, during the summer season [74]. The temperate continental climate with a marine influence is characterised by summers with heat attenuated by the sea breeze [75]. The duration of the sun's brightness is 140 days per year [76]. Precipitation is low, below $400 \mathrm{~mm} /$ year, Constanța being in the area with the lowest probability of precipitation of the entire county. The air temperature registers values of over $30^{\circ} \mathrm{C}$ in July, August, and September [72]. Located in a strongly ventilated area, Constanța does not face major problems in terms of air pollution. In addition, in the category of natural resources, we mention the existence of the lake complex formed by Tăbăcărie Lake (with an area of 99 ha, fresh water) and Siutghiol Lake $\left(19 \mathrm{~km}^{2}\right.$, fresh water, depth $2.5 \mathrm{~m}$ - used for water skiing and yachting), on which Ovidiu Island is located, with an area of 2 ha.

The tourist offer, based on the combination of natural resources, has the following structure: heliomarine cure (sea and sun baths, recommended for rest and relaxation) and thalassotherapy (walks on the fine sand of the beaches, walking in the water, and inhalation of aerosols), and the beating/action of waves and floating in the sea air, recommended for diseases of the circulatory system, locomotor, respiratory, nutritional diseases, etc. [77]. On the other hand, the low waves and the low salinity favour the practice of water sports.

From the category of anthropic resources, present in the tourist offer of Constanta municipality, we mention accommodation, food, leisure, and culture units. The accommodation capacity of the entire Romanian coast was, on 31 July 2020, 89,304 accommodation places [69]. The tourist accommodation capacity of Constanta city and Mamaia was on the same date 24,164 accommodation places (3593 accommodation places in Constanța and 20,571 accommodation places in Mamaia (data provided by the County Directorate of Statistics Constanța [69]). The accommodation capacity of Constanța and Mamaia accounts for $27 \%$ of the total accommodation capacity on the coast. In total, there were 155 accommodation units, of which 63 units located in Constanța and 92 units in Mamaia. Most of the accommodation units are hotels, of which $60 \%$ are 2-3 star hotels and 23\% are $4-5$ star hotels [72]. In the structure of some hotels, there are conference rooms (14 in Constanța 
and 41 in Mamaia), restaurants (21 in Constanța and 63 in Mamaia), SPA centres, saunas, fitness rooms, and beauty salons. The accommodation base indicates a good premise for the sustainable competitiveness of the destination [78]. Museums, theatres, historical buildings, places of worship, archaeological sites, the Aquarium, the Dolphinarium, the Natural Microreservation, the Astronomical Observatory, amusement parks, and other entertainment facilities, as well as shopping centres, represent the points of tourist attraction in Constanta. Tomis Tourist Port and the Old Town host restaurants and terraces with Turkish, Greek, Italian, or traditional Romanian cuisine, cafes, and gift shops.

Constanta ensures the conditions for practicing a diversity of forms of tourism, for many segments of tourists, such as summer tourism, relaxation and landscape tourism, health tourism (wellness), adventure tourism, sports tourism, leisure tourism, cultural tourism, business tourism, and MICE (meetings, incentives, conventions, and events) tourism. However, most of these forms of tourism are practiced only during the summer season, especially due to the action of natural factors. Therefore, the actual tourism season duration is about 2.5 months, between mid-June and the beginning of September. If we consider the effect of Constanta's tourist attraction, due to the potential of natural and anthropic resources, but also its specific aspects (the largest port city and important economic/business centre of the country), we can say that it is a place of great congestion throughout the year, but more obviously during the summer season. The population of Constanta feels in different forms and intensities the positive aspects, but also the negative ones, of being the inhabitants of a city with a tourist vocation.

In the last ten years, Constanta and Mamaia have witnessed a rapid growth of the tourism industry, representing one of the most attractive tourist destinations in Romania. In 2009, the number of tourists was 0.45 million, while in 2019 the indicator was about $50 \%$ higher, reaching 0.62 million tourists. The data reveal two important aspects. First, the city of Constanta is one of the most attractive tourist cities in Romania, the number of tourists in 2019 being equal or even higher than other entire counties listed as next in top 10 touristic destinations in Romania (such as Cluj County (0.65 million in 2019) or Sibiu County (0.57 million in 2019)). Secondly, given that Constanta is a summer tourism destination, it should be emphasised that the pressure of tourism in the city is concentrated in about 2.5 months per year during the tourist season, raising concerns about looming overtourism. In particular, the residents got a glimpse at overtourism due to an event that took place in Constanta three years in a row in July, starting with 2017, the Neversea festival. This event gathered each year during 3-4 days over 200,000 participants [79]. The event announced for 2020 was expected to be the largest thus far, however, due to the general situation, the event was cancelled. The year 2020 revealed an unprecedented situation in the history of the tourism industry in the last three decades due to the COVID-19 pandemic. Constanta and Mamaia registered a decrease in the number of tourists, between January and August 2020, with only 0.317 million tourists, in line with the general international trend. However, the tourism pressure on the Romanian coast during the tourist peak season did not decrease significantly. The data provided by the National Institute of Statistics [80] show that in July 2020 the number of tourists arriving on the entire Romanian coast was $34.6 \%$ of the total number of tourists in Romania compared to only $25.5 \%$ in July 2019 , showing an increase in attractiveness as a tourist destination for domestic tourism in the pandemic context.

\subsection{The Sample Selection}

The sample size $(\mathrm{N})$ was determined using the formula [81]:

$$
N=\frac{\frac{z_{\alpha}^{2} p(1-p)}{e^{2}}}{1+\frac{z_{\alpha}^{2} p(1-p)}{e^{2} P}},
$$

where $P$ is the size of the general population, $z_{\alpha}$ is the $\mathrm{z}$-score, $e$ is the margin error, and $p$ is the probability to obtain an affirmative answer to the question addressed. 
In this study, $P=263,001$ (representing the adult population, aged above 18 years in the region under survey, according to the official statistics provided by the County Statistics Directorate [69] for the year 2019), and $\mathrm{z}_{\alpha}=1.96$, corresponding to a confidence level of $95 \%, e=0.05, p=0.5$. The resulting sample size was 384 .

The research targeted the adult residents of Constanta city and was conducted between October and November 2020. The research was conducted online, using Google Forms. The link to the questionnaire was posted on social networks and on local groups of interest for the residents. In total, 556 filled in questionnaires were received. To obtain a representative sample, the sample selection was achieved using proportionate stratification sampling, based on the age criterion and using the data provided by the County Statistics Directorate [69] on the resident population of Constanta city. The structure of the adult resident population function of age group is the following: 18-25 years, 8\%; 26-35 years, $17 \%$; 36-45 years, $20 \%$; 46-55 years, $17 \%$; 56-65 years, $17 \%$; and over 66 years, $21 \%$. Therefore, to compile the sample, 384 questionnaires were extracted from the total number of questionnaires received, using the first in-first out principle, until the necessary proportion of respondents for each age group was achieved.

\subsection{The Research Tool}

The research instrument employed was a questionnaire integrating several sections. In the design of the questionnaire, there were integrated different sections, considering also previous research $[6,52,82]$. The first section focused on obtaining information about the respondents' attitude toward the tourist activity in the city, the living conditions in Constanta as a tourist city, and the intensity of their interaction with tourists. The attitude toward the tourist activity in the city was evaluated on a five-point semantic differential from 1 = very little acceptance to $5=$ very high acceptance. The living conditions were evaluated on a five-point semantic differential from $1=$ very unsatisfying to 5 = very satisfying. The interaction with the tourists regarded as frequency and mode of interaction was evaluated on a three-point semantic differential from $1=$ low to $3=$ high. The second section focused on the impact of the tourist activity on the image of Constanta and on its development considering a series of elements such as employment rate, income, living standard, public revenues, residents' behaviour, drug and alcohol consumption, prostitution, organised crime, vandalism, traffic, public health, spatial planning and landscaping, and sustainable development opportunities. For evaluation, five-point semantic differentials from 1 = severe worsening to $5=$ significant improvement were used. The next section focused on the evaluation of the tourist behaviour (on a five-point scale from $1=$ very little to $5=$ very high) using a series of positive attributes, such as friendly, polite, honest, happy, civilised, and careful toward the environment, as well as a series of negative attributes such as arrogant, annoying, threatening, disruptive, or dangerous to the environment. Afterwards, the respondents were asked to indicate the places they encountered tourists most often (e.g., beaches, shops, food outlets, playgrounds, parks, tourist attractions or public transport), the places where their interaction with tourists was positive and those where the interaction was mostly negative. Next, the focus was on identifying the negative aspects encountered by residents during the tourist season, such as crowding in the streets, shops, food outlets, sanitary units, lack of parking spaces, increased pollution, price increases for different products or services, noise, crime, rent increases, and problems with the supply of electricity and water, as well as the impact of these elements on the residents' lives. Subsequently, the estimated impact of the tourists and tourist activity on the sustainable development of the city was investigated and whether the tourist number should increase, decrease, or remain constant. The final section of the questionnaire aimed at obtaining information regarding the sociodemographic characteristics of the respondents, such as gender, age, studies, professional status, and monthly average income per family member. 


\subsection{Modelling}

Firstly, Principal Component Analysis (PCA) was used for determining the main elements which influence the attitude of the residents towards the tourism activity development in their community. This is a widely used reduction technique for extracting the most significant variables (in terms of proportion of the total variance explained) that describe a phenomenon or process [83]. Since the method is widely utilised, we do not insist on it.

Secondly, we determined two multiple linear regression models that describe the relationship between the acceptance and support level of residents and the other significant variables detected during the previous step. We selected the best model based on the Akaike (AIC) and Schwarz (SCH) criteria: the best model is that with the smallest AIC [84] and BIC [85].

\subsection{Limitations of Research}

The research methodology has several limitations. Given that the participation in the research was voluntary, one may consider that the respondents may have actually favoured tourist activity and thus be willing to take the survey. Secondly, the research took place outside the tourist season; therefore, the respondents may have been more tolerant with regard to the potential negative effects of tourism. Furthermore, the research was conducted in an exceptional time, due to the pandemic, and the entire summer tourist season of 2020 was rather atypical.

\section{Results and Discussion}

Table 1 summarises the sample structure.

Table 1. Characteristics of the sample.

\begin{tabular}{|c|c|c|c|c|c|c|c|}
\hline & \multicolumn{2}{|c|}{ Gender } & \multicolumn{5}{|c|}{ Studies } \\
\hline & Female & Male & Elementary education & \multicolumn{2}{|c|}{ Secondary education } & \multicolumn{2}{|c|}{ Bachelor and Post-university } \\
\hline$(\%)$ & 57.55 & 42.45 & 0.52 & \multicolumn{2}{|c|}{13.02} & \multicolumn{2}{|c|}{86.46} \\
\hline \multicolumn{8}{|c|}{ Socio-professional status } \\
\hline & Employees & Students & Entrepreneurs & Freelancers & Retired & $\begin{array}{l}\text { Stay-at-home } \\
\text { persons }\end{array}$ & Unemployed \\
\hline$(\%)$ & 57.29 & 19.01 & 11.46 & 4.69 & 4.17 & 2.08 & 1.30 \\
\hline \multicolumn{8}{|c|}{ Income (Lei) } \\
\hline & $1346-1500$ & $1501-2500$ & $2501-3500$ & $3501-4500$ & $4501-5500$ & $5501-6500$ & $>6500$ \\
\hline$(\%)$ & 13.02 & 22.04 & 19.01 & 15.10 & 8.33 & 7.03 & 15.10 \\
\hline
\end{tabular}

Most respondents $(86.7 \%)$ have been living in Constanta for more than five years, $9.9 \%$ for less than five years, and only $3.4 \%$ have been living in the city for less than a year. Overall, $86.2 \%$ of the respondents consider that there are significant differences in the living conditions in Constanta as a touristic city compared to other cities, only $6.8 \%$ consider that there are no significant differences, and $7.0 \%$ do not have an opinion on the matter. The respondents consider the living conditions in Constanta as a tourist city as averagely satisfying (with a mean score of 2.98 , on a five-point semantic differential scale from $1=$ very unsatisfying to $5=$ very satisfying).

To evaluate the residents' general stance toward tourist activity in the city a fivepoint semantic differential (from $1=\operatorname{do}$ not favour at all to $5=$ very much in favour) was employed. Most of the respondents $(69.5 \%)$ ticked the very much in favour option, while only $0.8 \%$ do not favour under any circumstances the tourist activity. The mean score obtained was 4.52 , indicating that residents are highly in favour of tourism. The results are in accordance with several previous findings $[3,7,46,52]$ while other studies revealed a more reserved attitude toward tourism $[14,41]$. 
Overall, $56.3 \%$ of the respondents evaluated their contact with tourists in terms of both frequency and mode of interaction as medium, $23.4 \%$ evaluated their contact as high, and $20.3 \%$ as minimal.

As far as the impact of the tourist activity on the image of the city is concerned, most respondents considered it was contributing to the improvement of the city image $(65.4 \%)$, while only 13.2\% considered it had a negative impact. Andereck et al. [3] and King et al. [52] revealed similar results, indicating that tourism contributed to improving the destination image. Most respondents considered that tourism has a fairly positive impact on employment rate, public income, and income and life standard of residents. Several previous studies revealed that tourism had a general economic positive impact $[3,7,23,46,52,82]$, while other studies concluded that the economic benefits of tourism were not perceived as particularly significant $[14,41]$. At the same time, our research revealed that tourism was accountable for the increase in negative phenomena such as alcohol and drug consumption, prostitution, crime, and vandalism. Previous findings also revealed several negative phenomena related to tourism: alcoholism, individual and organised crime, drugs addiction, and prostitution $[3,23,52,82]$. Further, our study revealed that residents' hospitality, morality, and honesty; residents' attitude towards labour, mutual trust, and good behaviour; city traffic; public health; spatial planning and landscaping; and sustainable development opportunities in the city seemed to be rather negatively impacted by the tourist activity. By contrast, King et al. [52] concluded that tourism had no impact on the morality, politeness, and honesty of residents and had a positive impact on confidence among people. Previous studies indicated a negative perceived impact of tourism on city traffic [3,7,14,23,41,52], public services [14], and the environment $[7,14]$, while other studies concluded that tourism had a rather positive impact on the environment [23].

Regarding the residents' characterisation of tourists' behaviour, a series of positive attributes (friendly, polite, honest, happy, civilised, and careful toward the environment) was provided, as well as a series of negative ones (arrogant, annoying, disruptive, and dangerous to the environment) evaluated on a five-point semantic differential from 1 = very little to $5=$ very high. The mean score for the positive behaviour was 2.65 and for the negative behaviour was 2.59 , thus indicating a balanced attitude of the residents towards tourists' behaviour.

Residents encounter tourists mostly on the beach $(94.8 \%)$, in restaurants, cafes, or bars $(80.5 \%)$, in shops $(69.3 \%)$, at tourist attractions $(64.3 \%)$, in the streets $(47.1 \%)$, in public transport means $(28.9 \%)$, and in parks and playgrounds (19\%). Other places that were indicated but with less frequency included the train station and medical clinics. These encounters resulted in both positive and negative experiences. Positive experiences of tourists' encounters were as follows: on beaches (36.4\%), in shops (19.5\%), in the streets $(14.1 \%)$, in parks and playgrounds $(10.2 \%)$, at restaurants, cafes, and bars $(33.6 \%)$, at tourist attractions (34.4\%), and in public transportation means (6.5\%). Overall, $20.3 \%$ stated they did not have any positive experience when encountering tourists. Negative experiences were on beaches $(57.3 \%)$, in shops $(39.1 \%)$, in the streets $(37.8 \%)$, in restaurants, cafes, and bars $(31.5 \%)$, in public transport means $(22.7 \%)$, at tourist attractions $(16.4 \%)$, and in parks and playgrounds (13.8\%). Overall, $18.2 \%$ revealed they did not have any negative experience with tourists.

The negative aspects encountered during tourist season included: lack of parking spaces $(89.6 \%)$, traffic congestions $(82 \%)$, prices increases $(69 \%)$, deterioration in city cleanness $(66.7 \%)$, increased noise $(59.6 \%)$, pollution $(56.5 \%)$, overcrowded restaurants, cafes, bars, and clubs (51\%), overcrowded shops (45.3\%), rent increases $(44.8 \%)$, tiredness and nervousness of overworked employees $(42.4 \%)$, overcrowded tourist attraction sites $(36.5 \%)$, increase in criminal offenses (33.3\%), overcrowded medical units (23.4\%), and unavailability of some products/services $(18 \%)$. Next, the impact of the negative aspects enumerated above was evaluated using a five-point semantic differential from $1=$ very low impact to $5=$ very high impact. The lack of parking spaces and traffic congestions had the highest impact, with average scores of 4.52 and 4.23, respectively. High impacts were reported 
also for increased pollution (4.05), increases in prices of products and services (4.08), deterioration of city cleanness (4.03), and increased noise (3.93). Lower impacts, although still significant, were reported for the other negative aspects under analysis: overcrowded restaurants, cafes, bars, and clubs (3.78), overcrowded shops (3.78), tiredness and nervousness of overworked employees (3.61), overcrowded tourist attractions (3.60), increase in criminal offenses (3.61), overcrowded medical units (3.50), and unavailability of some products/services (3.48). Previous studies also indicated several negative perceived consequences of tourism activity: traffic congestions [3,52], overcrowding [7], prices and general cost of living increases [14,31], litter [3,31], and pollution [23].

The impact of tourist activity on the sustainable development of the city was also evaluated using a five-point semantic differential from $1=$ high negative impact to $5=$ high positive impact. The average score was 3.76 revealing a medium positive perceived impact. However, $52.3 \%$ of the respondents considered that the number of tourists should increase, while only $9.9 \%$ considered it should decrease. The rest of the respondents considered it should remain at the current level (27.6\%), while $10.2 \%$ did not have an opinion on the matter.

The following indexes were computed:

- Acceptance and support for tourism index (IA). The index was calculated as an average of four variables referring to favourability toward tourism, general living conditions in Constanta city as a tourist city, the impact of tourism on city image, and opinion on whether tourists' numbers should increase/decrease or remain at the current level.

- City development index (IDO). The index was calculated as an average impact of economic variables (employment, public income, individual income, and products and services' prices), social variables (standard of living, quality of life, resident behaviour and hospitality, morality and honesty, attitude toward labour, mutual trust, good and civilised behaviour, and spatial planning and landscaping), and legal, safety, and public health variables (alcohol and drug consumption, crime, organised crime, prostitution, vandalism, public health, and traffic).

- Impact on residents' quality of life index (IV). The index was calculated as an average of several variables' impact on residents' lives (overcrowded streets, tourist attractions, shops, restaurants, cafes, clubs, and medical clinics; tiredness and nervousness of employees; lack of parking spaces; high pollution; increased noise; rise in crime; increased prices of products and services; unavailability of certain products and service; and city cleanness deterioration).

- City sustainable development Index (IDD). It was calculated based on the residents' overall evaluation of tourism impact on the sustainable development of the city.

- Tourist behaviour index (ICT). It was calculated as a difference between two indexes, Positive tourist behaviour index (friendly, polite, honest, happy, civilised, and careful toward the environment) and Negative tourist behaviour index (arrogant, annoying, threatening, disruptive, and dangerous to the environment).

The basic statistics of the study variables are presented in Table 2.

Table 2. Basic statistics of the indexes and variables.

\begin{tabular}{cccccccc}
\hline Basic Statistics & IA & IDO & IV & IDD & ICT & CT & LT \\
\hline Mean & 3.228 & 2.747 & 3.860 & 3.766 & 0.018 & 2.031 & 2.833 \\
Median & 3.250 & 2.765 & 4.000 & 4.000 & 0.000 & 2.000 & 3.000 \\
Mode & 3.500 & 3.000 & 5.000 & 3.000 & 0.000 & 2.000 & 3.000 \\
Minimum & 1.000 & 1.000 & 1.000 & 1.000 & -3.400 & 1.000 & 1.000 \\
Maximum & 4.500 & 5.000 & 5.000 & 5.000 & 4.000 & 3.000 & 3.000 \\
Range & 3.500 & 4.000 & 4.000 & 4.000 & 7.400 & 2.000 & 2.000 \\
Standard Deviation & 0.579 & 0.919 & 0.789 & 1.026 & 1.363 & 0.661 & 0.455 \\
Variance & 0.335 & 0.844 & 0.623 & 1.052 & 1.857 & 0.437 & 0.207 \\
Kurtosis & 0.705 & -0.651 & 0.765 & -0.242 & 1.149 & -0.705 & 7.203 \\
Skewness & -0.656 & 0.133 & -0.825 & -0.481 & 0.328 & -0.034 & -2.800 \\
\hline
\end{tabular}


While the average values are closer to the maximum for IA, IV, and IDD indexes, those of IDO and ICT are closer to their minima. For CT (perceived contact intensity with tourists), the mean, median, and mode are almost equal, showing distribution to be approximately symmetric. The mean, median, and mode have close values for IA, IDO, and ICT reflected in small values of skewness. IA, IV, and IDD are left-skewed, while IDO and ICT are right-skewed.

The standard deviation (and variance) is small for IA, CT, and LT (community attachment and duration of residence in the city), indicating a small deviation from the average, but it increases for the other series, the highest one being noticed for the composite index that indicates the tourist behaviour (ICT). This index records the highest range, as well.

To study the residents' attitude about the impact of the tourists on the city and their interaction with the tourists, Principal Component Analysis was performed. The study variables are IA, IDO, IV, IDD, ICT, CT, and LT. From the analysis of the obtained principal components (PC), it results that the first two components have corresponding eigenvalues greater than 1 (Figure 1) and explain $47.8 \%$ of the total variance, whereas, to explain more than $80 \%$ of the variance of the study phenomena, five PCs are necessary (Table 3 ).

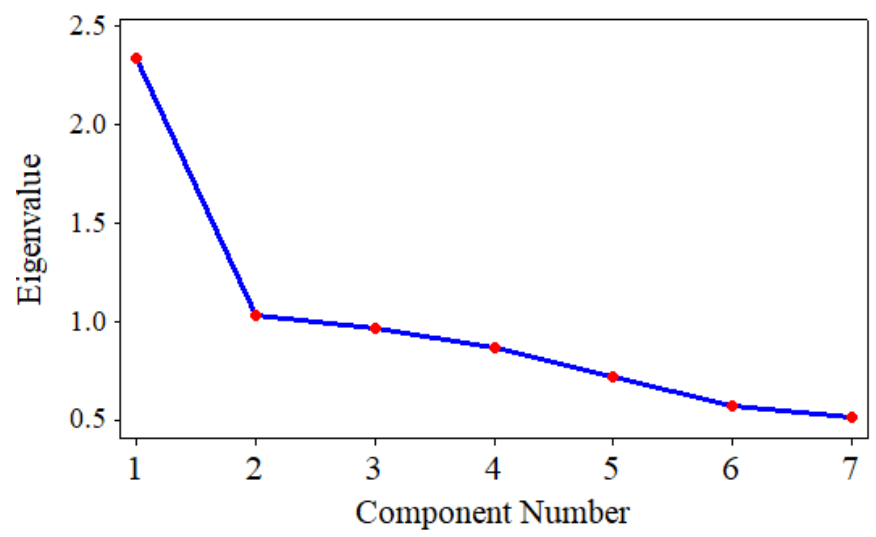

Figure 1. Scree plot.

Table 3. Principal components, their corresponding eigenvalues and variances.

\begin{tabular}{lccccccc}
\hline & PC1 & PC2 & PC3 & PC4 & PC5 & PC6 & PC7 \\
\hline Eigenvalue & 2.3437 & 1.0054 & 0.9768 & 0.8845 & 0.7100 & 0.5670 & 0.5127 \\
Proportion & 0.335 & 0.147 & 0.138 & 0.124 & 0.102 & 0.081 & 0.073 \\
Cumulative & 0.335 & 0.478 & 0.618 & 0.744 & 0.846 & 0.927 & 1.000 \\
\hline
\end{tabular}

Figure 2 presents the biplot and Table 4, the factor loadings on each component. Figure 2 shows that the highest influence on PC1 is that of IDD, IA, and IDO, while on PC2 it is LT, a fact confirmed by the values from Columns 2 and 3 of Table 3. The highest influence on PC3, PC4 and PC5 are those of IV and CT, IV and CT, and ICT, respectively.

Taking into account only the first two components, one may notice that the attitude of the residents is mainly influenced by: (1) IA, IDD, and IDO (negative correlation), which measure the acceptability of the residents on the touristic impact on the city and its sustainable development; and (2) how long the inhabitant has lived in the city. 


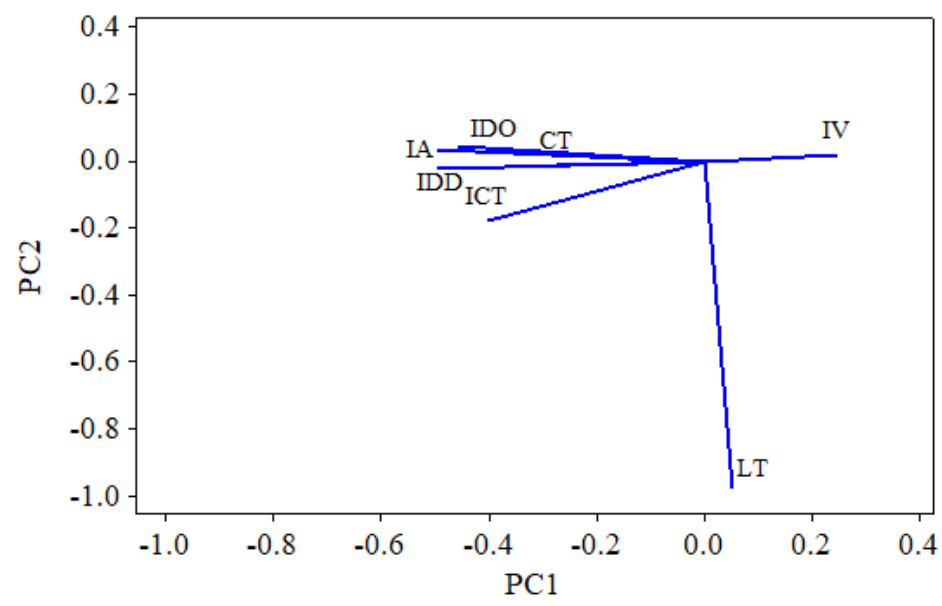

Figure 2. Biplot.

Table 4. Factor loadings.

\begin{tabular}{cccccccc}
\hline & PC1 & PC2 & PC3 & PC4 & PC5 & PC6 & PC7 \\
\hline IA & -0.494 & 0.035 & 0.206 & 0.004 & -0.147 & 0.538 & -0.633 \\
IDO & -0.456 & 0.047 & 0.066 & 0.361 & -0.381 & -0.703 & -0.127 \\
IV & 0.246 & 0.021 & 0.668 & 0.658 & 0.188 & 0.124 & -0.092 \\
IDD & -0.497 & -0.022 & -0.166 & 0.188 & -0.196 & 0.382 & -0.720 \\
ICT & -0.404 & -0.178 & -0.219 & 0.171 & 0.841 & -0.127 & 0.068 \\
CT & -0.274 & -0.010 & 0.665 & -0.610 & 0.152 & -0.197 & 0.223 \\
LT & 0.053 & -0.982 & 0.061 & 0.003 & -0.169 & 0.004 & -0.033 \\
\hline
\end{tabular}

Note: The bold numbers show the highest contributions on the first five components.

Taking into account the previous results, we built different models to describe the population's attitude. The most relevant emphasise the dependence of the IA index on some composite indexes and variables in the study. These are of the following type:

1. $\mathrm{IA}=\mathrm{F}(\mathrm{IDO}, \mathrm{IDD}, \mathrm{ICT}, \mathrm{CT})$

2. $\mathrm{IA}=\mathrm{F}(\mathrm{IDO}, \mathrm{IV}, \mathrm{IDD}, \mathrm{CT})$,

where $\mathrm{F}$ is a function to be determined.

The equation of the first model is:

$I A_{i}=0.2773 \times I D O_{i}+0.3893 \times I D D_{i}-0.0523 \times I C T_{i}+0.4578 \times C T_{i}+\varepsilon_{i}, i=1, \ldots, 384$,

where $\varepsilon_{i}$ is the random variable.

The second model is:

$$
I A_{i}=0.2064 \times I D O_{i}+0.2215 \times I V_{i}-0.3016 \times I D D_{i}+\varepsilon_{i}, \quad i=1, \ldots, 384,
$$

where $\varepsilon_{i}$ is the random variable.

To validate the models, the t-tests on the equations' coefficients, the F-test on the model, and the tests on the residuals (normality (the Ryan-Joiner test), homoscedasticity (the Bartlett and Levene test), and absence of correlation (autocorrelation function)) were carried out. All statistical tests were performed at a 5\% significance level using Minitab 15.

The $p$-values from the t-tests for the regression coefficients for Model (1) have values less than 0.0279 and for Model (2) less than $1.7 \times 10^{-9}$. The F-statistics for testing the significance of the models were less than $3.3 \times 10^{-294}$. Thus, there is enough evidence to reject the null hypotheses that the coefficients are not significant and the models are not significant, respectively. 
The results of the statistical tests on the residual are presented in Figures 3 and 4. The $p$-values from the Ryan-Joiner test (RJ), Bartlett, and Levene tests are above $0.100>0.05$, so the normality and homoscedasticity hypotheses of the residuals cannot be rejected. Since the values of the autocorrelation functions are inside the confidence intervals (at 95\% confidence level), there is not enough evidence to reject the hypothesis that the residuals in both models are not correlated.
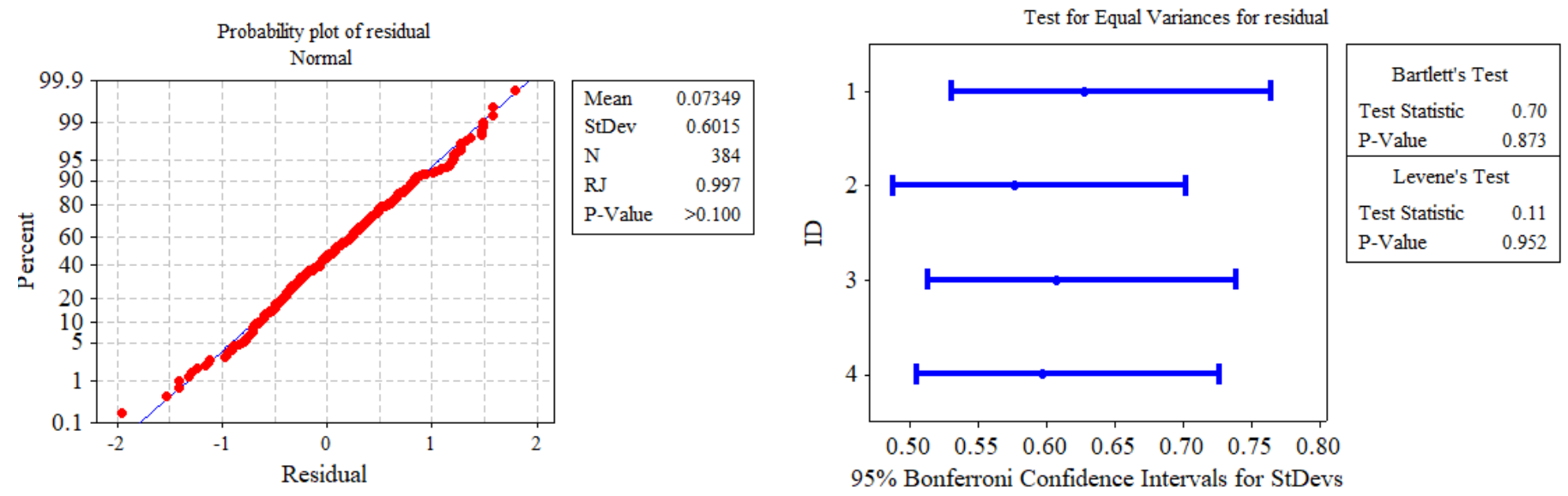

Autocorrelation Function for residual

(with $5 \%$ significance limits for the autocorrelations)

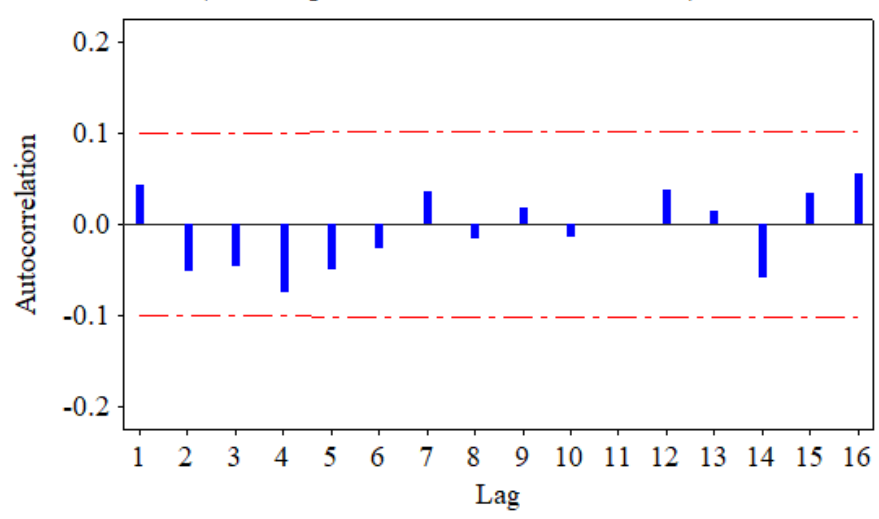

Figure 3. Results of the statistical tests on the residuals from Model (1).

Comparing the value of the determination coefficients, it turns out that the smallest resulted from Model (2) (0.96594, compared to 0.97243). Based on this coefficient, the best model is the second one. To verify this hypothesis, the Akaike (AIC) and Schwarz (SCW) criteria were computed. The results are:

- $\quad$ AIC $=-0.9836$ and BIC $=-0.9424$ (for model (1))

- $\quad$ AIC $=-1.1949$ and $\mathrm{BIC}=-1.1538$ (for model (2))

Based on both criteria, the best model is given by Equation (2). 

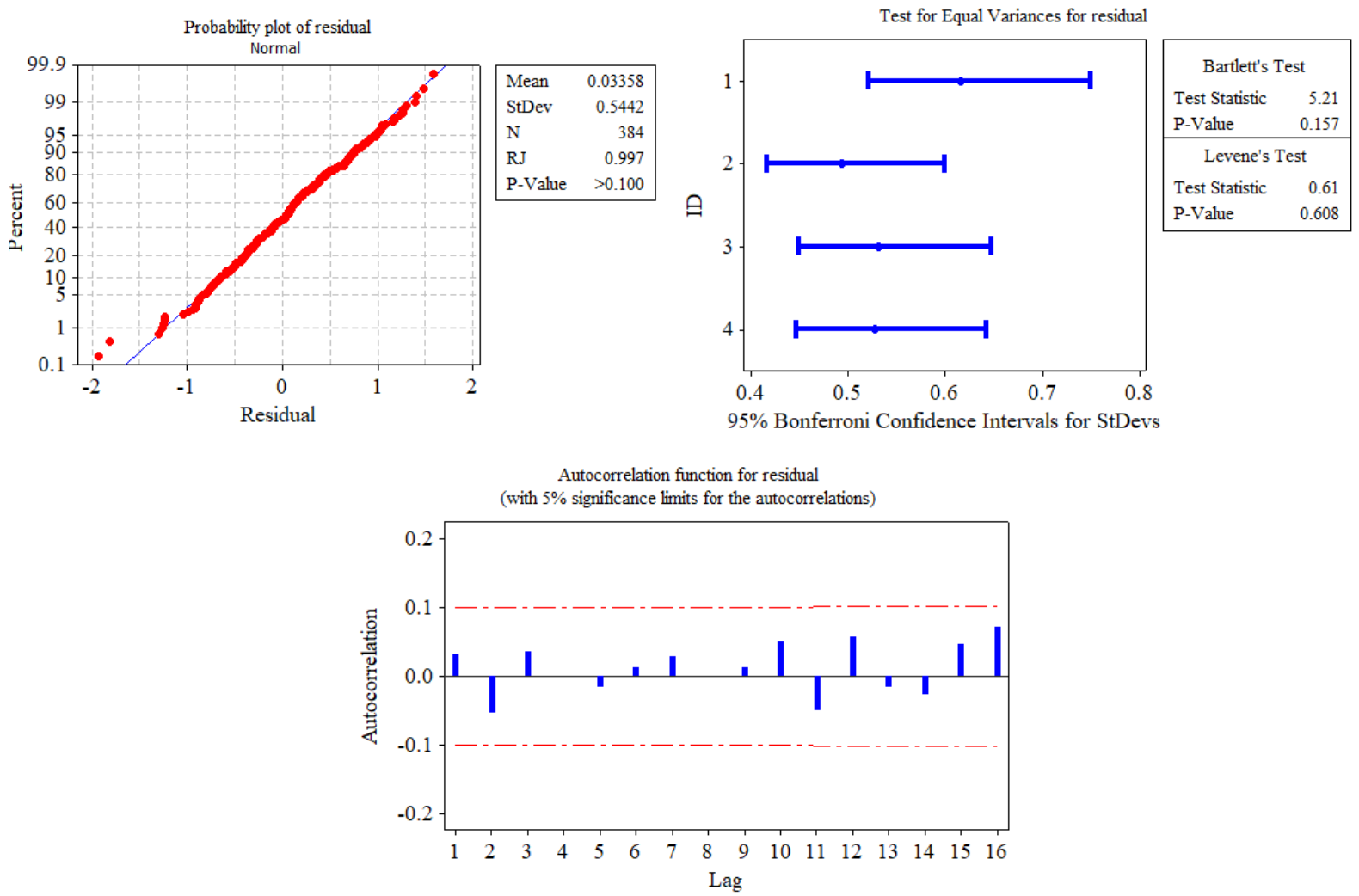

Figure 4. Results of the statistical tests on the residuals from Model (2).

\section{Conclusions}

The research results reveal that residents are highly in favor of tourism activity in their city and support tourism expansion and further development. Most respondents considered that tourism contributed to the improvement of the city image. The majority identified a fairly positive impact of tourism on employment rate, public income, and income and life standard of residents. At the same time, tourism was accountable for the increase in negative phenomena such as alcohol and drug consumption, prostitution, crime, and vandalism. Further, our study revealed that residents' hospitality, morality and honesty; residents' attitude towards labour, mutual trust, and good behaviour; city traffic; public health; spatial planning and landscaping; and sustainable development opportunities in the city seemed to be rather negatively impacted by the tourist activity. The impact of tourist activity on the sustainable development of the city was perceived as medium positive, while most respondents considered that the number of tourists should increase. At the same time, the evolution in the number of tourists during the past decade indicates a tendency of growth (with the highest number in 2019), thus raising concerns about overtourism. However, 2020 was an atypical year that hindered tourist activity and cancelled all events with numerous participants. Otherwise, all evidence indicates that the number of tourists in 2020 would have risen above the 2019 level, thus increasing the pressure felt by the residents.

Regarding the factors that influence the residents' acceptability toward tourism, the results of the modelling reveal that it depends on several variables and computed indexes: city development index, impact on residents' quality of life index, sustainable development index, and perceived intensity of contact with tourists. The results may be useful in the improvement of local strategies regarding tourism and the sustainable development of the city.

The present study contributes to the existing literature on the subject by bringing forth the case of a coastal city, with an intense sun-lust tourism activity. The residents' perception 
on tourism activity has only been marginally approached in Romania, and our study aims at filling this gap.

Further research directions could include a more inclusive study comprising the entire Romanian cost, or even comparison with other coastal cities by the Black Sea. To achieve comparability of results, the study could be replicated during high season and without any restrictions such as those imposed by the pandemic in 2020. Adjacent research could be designed to include the phenomenon of overtourism and the challenges for city authorities, tourism businesses, and residents.

Author Contributions: A.-D.M., conceptualisation, methodology, formal analysis, writing-original draft preparation, and supervision; C.D., conceptualisation, formal analysis, resources, and writingreview and editing; A.B., methodology, software, validation, and data curation; M.J., data curation and investigation; and I.-D.J., investigation and data collecting. All authors have read and agreed to the published version of the manuscript.

Funding: This research received no external funding.

Data Availability Statement: Data will be available on request.

Conflicts of Interest: The authors declare no conflict of interest.

\section{References}

1. Getz, D. Models in Tourism Planning: Towards Integration of Theory and Practice. Tour. Manag. 1986, 7, 31-32. [CrossRef]

2. Long, P.T.; Perdue, R.R.; Allen, L. Rural Resident Tourism Perceptions and Attitudes by Community Level of Tourism. J. Travel Res. 1990, 28, 3-9. [CrossRef]

3. Andereck, K.; Valentine, K.; Knopf, R.; Vogt, C. Residents' perceptions of community tourism impacts. Ann. Tour. Res. 2005, 32, 1056-1076. [CrossRef]

4. Ap, J. Residents' Perceptions on Tourism Impacts. Ann. Tour. Res. 1992, 19, 665-690. [CrossRef]

5. Liu, J.L.; Var, T. Resident Attitudes to Tourism Impacts in Hawaii. Ann. Tour. Res. 1986, 13, 193-214. [CrossRef]

6. Pizam, A. Tourism Impacts: The social costs to the destination community as perceived by its residents. J. Travel Res. 1978, 16, 8-12. [CrossRef]

7. Abdollahzadeh, G.; Sharifzadeh, A. Rural Residents' Perceptions toward Tourism Development: A Study from Iran. Int. J. Tour. Res. 2014, 16, 126-136. [CrossRef]

8. McGehee, N.G.; Andereck, K.L. Factors Predicting Rural Residents' Support of Tourism. J. Travel Res. 2004, 43, 131-140. [CrossRef]

9. Brida, J.G.; Osti, L.; Faccioli, M. Residents' perception and attitudes towards tourism impacts, a case study of the small rural community of Folgaria (Trentino-Italy). Benchmarking Int. J. 2011, 18, 359-385. [CrossRef]

10. Weaver, D.; Lawton, L. Resident Perceptions in the Urban-Rural Fringe. Ann. Tour. Res. 2001, 28, 439-458. [CrossRef]

11. Su, Q.; Cao, Y.; Lin, B. Comparative study on residents' perception of tourism impact at tourist places. Chin. Geogr. Sci. 2005, 15, 70-79. [CrossRef]

12. Mitchell, R.E.; Reid, D.G. Community Integration: Island Tourism in Peru. Ann. Tour. Res. 2001, 28, 113-139. [CrossRef]

13. Hanafiah, M.H.; Jamaluddin, M.R.; Zulkifly, M.I. Local community attitude and support towards tourism development in Tioman Island, Malaysia. Soc. Behav. Sci. 2013, 105, 792-800. [CrossRef]

14. Perez, E.A.; Nadal, J.R. Host community perceptions a cluster analysis. Ann. Tour. Res. 2005, 32, 925-941. [CrossRef]

15. Mensah, I. Effects of Socio-Demographic Characteristics and Perceived Benefits of Tourism on Community Participation in Tourism in the Mesomagor Area of the Kakum National Park, Ghana. Athens J. Tour. 2016, 3, 211-230. [CrossRef]

16. Rasoolimanesh, S.M.; Roldán, J.L.; Jaafar, M.; Ramayah, T. Factors influencing residents' perceptions toward tourism development: Differences across rural and urban world heritage sites. J. Travel Res. 2017, 56, 760-775. [CrossRef]

17. Cardoso, C.; Silva, M. Residents' perceptions and attitudes towards future tourism development: A challenge for tourism planners. Worldw. Hosp. Tour. Themes 2018, 10, 688-697. [CrossRef]

18. Koens, K.; Postma, A. Understanding and Measuring Visitor Pressure in Urban Tourism-A Study into the Nature and Methods Used to Manage Visitor Pressure in Six Major European Cities. Available online: https://www.celth.nl/sites/default/files/2018 -09/Voorkomen\%20van\%20bezoekersdruk\%20in\%20Europese\%20steden.pdf (accessed on 8 October 2020).

19. Escudero Gómez, L.A. Realities and problems of a major cultural tourist destination in Spain, Toledo Pasos. Rev. Tur. Patrim. Cult. 2018, 16, 617-636. [CrossRef]

20. Janusz, K.; Six, S.; Vanneste, D. Building tourism-resilient communities by incorporating residents' perceptions? A photoelicitation study of tourism development in Bruges. J. Tour. Futures 2017, 3, 127-143. [CrossRef]

21. Gilbert, D.; Clark, M. An exploratory examination of urban tourism impact, with reference to residents attitudes, in the cities of Canterbury and Guildford. Cities 1997, 14, 343-352. [CrossRef]

22. Ross, G.F. Resident Perceptions of the Impact of Tourism on an Australian City. J. Travel Res. 1992, 30, 13-17. [CrossRef] 
23. Tichaawa, T.M.; Moyo, S. Urban resident perceptions of the impacts of tourism development in Zimbabwe. Bull. Geogr. Socio-eco. Ser. 2019, 43, 25-44. [CrossRef]

24. Rogerson, C.M. Urban Tourism in the Developing World: The Case of Johannesburg. Dev. S. Afr. 2002, 19, 169-190. [CrossRef]

25. Haralambopoulos, N.; Pizam, A. Perceived impacts of tourism: The case of Samos. Ann. Tour. Res. 1996, 23, 503-526. [CrossRef]

26. Brunt, P.; Courtney, P. Host perceptions of sociocultural impacts. Ann. Tour. Res. 1999, 26, 493-515. [CrossRef]

27. Wang, Y.; Pfister, R.E. Residents' Attitudes toward Tourism and Perceived Personal Benefits in a Rural Community. J. Travel Res. 2008, 47, 84-93. [CrossRef]

28. Santisi, G.; Platania, S.; Paolillo, A. Land development and tourism policies: The assessment of the tourism from the point of view of the residents. Tur. Psicol. 2013, 1, 106-117.

29. Lankford, S.V. Attitudes and Perceptions toward Tourism and Rural Regional Development. J. Travel Res. 1994, 32 , 35-43. [CrossRef]

30. McCool, S.F.; Marin, S.R. Community Attachment and Attitudes towards Tourism Development. J. Travel Res. 1994, 32, 29-34. [CrossRef]

31. Perdue, R.R.; Long, P.T.; Allen, L. Resident support for tourism development. Ann. Tour. Res. 1990, 17, 586-599. [CrossRef]

32. Tosun, C. Host Perceptions of Impacts: A Comparative Tourism Study. Ann. Tour. Res. 2002, 29, 231-253. [CrossRef]

33. Nawijn, J.; Mitas, O. Resident Attitudes to Tourism and Their Effect on Subjective Well-Being: The Case of Palma de Mallorca. J. Travel Res. 2012, 51, 531-541. [CrossRef]

34. Pizam, A.; Jafari, J.; Milman, A. Influence of tourism on attitudes: US students visiting USSR. Tour. Manag. 1991, 12, 47-54. [CrossRef]

35. Lindberg, K.; Johnson, R.L. Modeling resident attitudes toward tourism. Ann. Tour. Res. 1997, 24, 402-424. [CrossRef]

36. Johnson, J.D.; Snepenger, D.J.; Akis, S. Residents perceptions of tourism development. Ann. Tour. Res. 1994, $21,629-642$. [CrossRef]

37. Liu, J.C.; Sheldon, P.J.; Var, T. Resident Perception of the Environmental Impacts of Tourism. Ann. Tour. Res. 1987, 14, 17-37. [CrossRef]

38. Gursoy, D.; Jurowski, C.; Uysal, M. Resident Attitudes: A Structural Modeling Approach. Ann. Tour. Res. 2002, 29, 79-105. [CrossRef]

39. Jurowski, C.; Uysal, M.; Williams, D.R. A theoretical analysis of host community resident reactions to tourism. J. Travel Res. 1997, 34, 3-11. [CrossRef]

40. Ko, D.W.; Stewart, W.P. A Structural Equation Model of Residents' Attitudes for Tourism Development. Tour. Manag. 2002, 23, 521-530. [CrossRef]

41. Látková, P.; Vogt, C.A. Residents' attitudes toward existing and future tourism development in rural communities. J. Travel Res. 2012, 51, 50-67. [CrossRef]

42. Rasoolimanesh, S.M.; Jaafar, M.; Kock, N.; Ramayah, T. A revised framework of social exchange theory to investigate the factors influencing residents' perceptions. Tour. Manag. Persp. 2015, 16, 345-355. [CrossRef]

43. Nicholas, L.N.; Thapa, B.; Ko, Y.J. Residents' perspectives of a World Heritage Site: The Pitons Management Area, St. Lucia. Ann. Tour. Res. 2009, 36, 390-412. [CrossRef]

44. Byrd, E.T.; Bosley, H.E.; Dronberger, M.G. Comparisons of Stakeholder Perceptions of Tourism Impacts in Rural Eastern North Carolina. Tour. Manag. 2009, 30, 693-703. [CrossRef]

45. Luštický, M.; Musil, M. Towards a Theory of Stakeholders' Perception of Tourism Impacts. Czech. J. Tour. 2016, 5, 93-110. [CrossRef]

46. Boley, B.; McGehee, N.; Perdue, R.; Long, P. Empowerment's and resident attitudes toward tourism: Strengthening the theoretical foundation through a Weberian lens. Ann. Tour. Res. 2014, 49, 33-50. [CrossRef]

47. McGehee, N.G. An agritourism systems model: A Weberian perspective. J. Sustain. Tour. 2007, 15, 111-124. [CrossRef]

48. Mody, M.; Woosnam, K.M.; Suess, C.; Dogru, T. Hapless victims or empowered citizens? Understanding residents' attitudes towards Airbnb using Weber's Theory of Rationality and Foucauldian concepts. J. Sustain. Tour. 2020. [CrossRef]

49. Maddox, R.N. Factors Contributing to Satisfaction with Tourism: The Resident view. In Tourism Services Marketing: Advances in Theory and Practice (Special Conference Series); Academy of Marketing Science, University of Miami: Miami, FL, USA, 1986; pp. 76-84.

50. Davis, D.; Allen, J.; Consenza, R. Segmenting Local Residents by Their Attitudes, Interests, and Opinions toward Tourism. J. Travel Res. 1988, 30, 45-48. [CrossRef]

51. Boley, B.B.; McGehee, N.G. Measuring empowerment: Developing and validating the Resident Empowerment through Tourism Scale (RETS). Tour. Manag. 2014, 45, 85-94. [CrossRef]

52. King, B.; Pizam, A.; Milman, A. Social impacts of tourism: Host perceptions. Ann. Tour. Res. 1993, 20, 650-665. [CrossRef]

53. Meimand, S.E.; Khalifah, Z.; Zavadskas, E.K.; Mardani, A.; Najafipour, A.A.; Ahmad, U.N.U. Residents' Attitude toward Tourism Development: A Sociocultural Perspective. Sustainability 2017, 9, 1170. [CrossRef]

54. Vargas-Sánchez, A.; Porras-Bueno, N.; de los Ángeles Plaza-Mejía, M. Explaining residents' attitudes to tourism: Is a universal model possible? Ann. Tour. Res. 2011, 38, 460-480. [CrossRef]

55. Szromek, A.; Kruczek, Z.; Walas, B. The attitude of tourist destination residents towards the effects of overtourism-Krakow case study. Sustainability 2020, 12, 228. [CrossRef] 
56. Kim, S.; Kang, Y. Why do residents in an overtourism destination develop anti-tourist attitudes? An exploration of residents' experience through the lens of the community-based tourism. Asia Pac. J. Tour. Res. 2020, 25, 858-876. [CrossRef]

57. Kuscer, K.; Mihalic, T. Residents' Attitudes towards Overtourism from the Perspective of Tourism Impacts and Cooperation-The Case of Ljubljana. Sustainability 2019, 11, 1823. [CrossRef]

58. Martín, M.J.; Martínez, G.J.; Fernández, S.J. An analysis of the factors behind the citizen's attitude of rejection towards tourism in a context of overtourism and economic dependence on this activity. Sustainability 2018, 10, 2851. [CrossRef]

59. Cheung, K.S.; Li, L.H. Understanding visitor-resident relations in overtourism: Developing resilience for sustainable tourism. J. Sustain. Tour. 2019, 27, 1197-1216. [CrossRef]

60. Gössling, S.; McCabe, S.; Chen, N. A socio-psychological conceptualisation of overtourism. Ann. Tour. Res. 2020, 84, 102976. [CrossRef]

61. Capocchi, A.; Vallone, C.; Pierotti, M.; Amaduzzi, A. Overtourism: A literature review to assess implications and future perspectives. Sustainability 2019, 11, 3303. [CrossRef]

62. Gonzalez, V.M.; Coromina, L.; Galí, N. Overtourism: Residents' perceptions of tourism impact as an indicator of resident social carrying capacity-Case study of a Spanish heritage town. Tour. Rev. 2018, 73, 277-296. [CrossRef]

63. Adie, B.A.; Falk, M.; Savioli, M. Overtourism as a perceived threat to cultural heritage in Europe. Curr. Issues Tour. 2019. [CrossRef]

64. Perkumiene, D.; Pranskuniene, R. Overtourism: Between the right to travel and residents' rights. Sustainability 2019, 11, 2138. [CrossRef]

65. Smith, M.K.; Pinke Sziva, I.; Olt, G. Overtourism and Resident Resistance in Budapest. Tour. Plan. Dev. 2019, 16, 376-392. [CrossRef]

66. Carballo, R.; Leon, C.; Carballo, M. Fighting overtourism in Lazarote (Spain). Worldw. Hosp. Tour. Themes 2019, 11, 506-515.

67. Mawby, R.I.; Tecău, A.S.; Constantin, C.P.; Chițu, I.B.; Tescașiu, B. Addressing the Security Concerns of Locals and Visitors for the Sustainable Development of Tourist Destinations. Sustainability 2016, 8, 524. [CrossRef]

68. Frînculeasa, M.N.; Chițescu, R.I. The perception and attitude of the resident and tourists regarding the local public administration and the tourism phenomenon. HOLISTICA 2018, 9, 137-152. [CrossRef]

69. Constanta County Directorate of Statistics. Available online: https://constanta.insse.ro/ (accessed on 15 October 2020).

70. Zona Metropilitana Constanta. Available online: http://www.zmc.ro/municipiul-constanta/ (accessed on 5 November 2020).

71. Romania Tourism. Available online: http://romaniatourism.com/constanta.html (accessed on 5 November 2020).

72. The Strategy for the Development and Promotion of Tourism in Constanta. Available online: http://www.primariaconstanta.ro/docs/default-source/documente-pwpmc/librarie-proiecte/strategia-de-dezvoltare-si-promovare-a-turismuluiin-municipiul-constanta.pdf?sfvrsn=2 (accessed on 15 December 2020).

73. Litoralul Romanesc. Available online: https://www.litoralulromanesc.ro/descriere_constanta.htm?gclid=EAIaIQobChMI4tD7z8 7y7AIVKUCRBR3_WAJrEAAYASAAEgJLR_D_BwEToate (accessed on 15 October 2020).

74. Bran, F.; Marin, D.; Simon, T. Economia Turismului și Mediului Înconjurător; Economica Publishing House: Bucharest, Romania, 1998.

75. Consiliul Judetean Constanta. Available online: http:/ / www.cjc.ro/ sectiune.php?s=55 (accessed on 20 October 2020).

76. Minciu, R. Economia Turismului, 2nd ed.; Uranus Publishing House: Bucharest, Romania, 2004.

77. Snak, O.; Baron, P.; Neacșu, N. Economia Turismului; Expert Publishing House: Bucharest, Romania, 2001.

78. Roman, M.; Roman, M.; Niedziolka, A. Spatial diversity of tourism in the countries of the European Union. Sustainability 2020, 12, 2713. [CrossRef]

79. Business Review. Available online: https://business-review.eu/bucharest-going-out/concerts/neversea-releases-the-2019 -aftermovie-207590 (accessed on 5 November 2020).

80. National Institute of Statistics. Available online: https://insse.ro/cms/en (accessed on 5 November 2020).

81. Daniel, W.W.; Cross, C.L. Biostatistics, a Foundation for Analysis in the Health Sciences, 10th ed.; Wiley: Hoboken, NJ, USA, 2013.

82. Milman, A.; Pizam, A. Social Impacts of Tourism on Central Florida. Ann. Tour. Res. 1988, 15, 191-204. [CrossRef]

83. Smith, L. A Tutorial on Principal Components Analysis. 2002. Available online: http://www.cs.otago.ac.nz/cosc453/student_ tutorials/principal_components.pdf (accessed on 8 September 2020).

84. Akaike, H. A new look at the statistical model identification. IEEE Trans. Automat. Contr. 1974, 19, 716-723. [CrossRef]

85. Schwarz, G.E. Estimating the dimension of a model. Ann. Stat. 1978, 6, 461-464. [CrossRef] 